generation: I wished the reader had been told what is the primary defect which has now been reoognized. I cannot imagine that a low caeruloplasmin level is the primary defect you are referring to. As everyone knows, there is a definite though small number of patients with Wilson's disease who have normal caeruloplasmin levels. The opposite, of course, also holds true.

I am left wondering whether abnormal copper metabolism is the primary defect you have in mind. With regard to that one could recall that patients have been reported $^{1-3}$ who had a frankly or questionably positive copper balance and who, to all intents and purposes, were not instances of Wilson's disease. But then, is dopamine deficiency the primary defect of Parkinson's disease? To be sure, knowledge of a dopamine deficiency and of a positive copper balanoe has notably advanced our understanding of paralysis agitans and Wilson's disease respectively. I think, however, that we have a long way to go before we can ever say that the "primary defect" of Wilson's disease has been recognized. Perhaps the beginning of that long way could be sighted in some recently published work, 4 should the reported finding be conclusively established.-I am, etc.,

Max-Planck-Institut für Psychiatrie,

A. P. ANzIL Munich

1 Gallyas, F., and Környey, S., Archive für $P$ ychiatrie und Nervenkrankheiten, 1968/1969,
212,33 .

Neurology, 19́72, 8, 251.

3 Willvonseder, R., Goldstein, N. P., MoCall, J. T., Yoss, R. E., and Taure, W. 'N., Neurology, Evans, G. W., Dubois, R. S.,
K. M., Science, 1973, 181, 1175.

\section{Coxsackie B Viruses and Diabetes Mellitus}

SIR,-Several studies have suggested that there may be a relationship between Coxsackie virus infections and diabetes mellitus. ${ }^{1}$ In 1951 Pappenheimer et al. found that Coxsackie $B$ viruses caused acinar pancreatitis in mice with sparing of the islets of Langerhans. However, Burch et al. . $^{4}$ reported that Coxsackie B1 and B4 also damaged the beta-clls of the pancreas. More recently Coleman et al..$^{5}$ found abnormal gluoose levels in six of 14 mice infected with Coxsackie B4. In our laboratory prototype strains of Coxsackie B1, B3, $B 4$, and B5 produced hyperamylasaemia and a decrease in the amylase content of the pancreas, but non-fasting gluoose levels and glucose tolerance tests were normal under a variety of experimental conditions. ${ }^{6}$

The present experiments were initiated to see whether fresh Coxsackie virus isolates (rather than prototype viruses that have been passaged numerous times in tissue culture and neonatal mice) were ous times in tissue culture and neonatal mice) were
capable of producing hyperglycemia in mice. Fourteen human isolates, passaged two or three times in monkey kidney cells, were kindly supplied by Dr. Edwin H. Lennette of the Viral and Ricketment of Health. Each virus preparation, containing ment $10^{5}$ median tissue culture infective doses (TCID ${ }_{50}$ ), was injected intraperitoneally into 15 CD-1 male mice 6-9 weeks of age. Serum amylase levels were determined by the blue starch sublevels were determined by the blue starch sub-
strate method and blood glucose levels by the strate method and blood
glucose oxidase method."

glucose oxidase method.
The fresh isolates all caused acinar pancreatitis manifested by hyperamylasaemia $(P<0.01$ for al but one of the strains of virus). The histological changes of acinar pancreatitis were indistinguishable from those found with prototype Coxsackie B viruses." - The mean non-fasting glucose levels were not significantly elevated; more important, none of the 200 mice tested had blood glucose none of the 200 mice tested had blood glucose normal. Glucose tolerance tests ${ }^{6}$ performed on 10 mice from each group about 14 days after infection mice from each group about 14 days after infection
revealed that none of the mice had elevated glucose levels. Histologically, the islets of Langerhans were essentially normal in all cases. In contrast to the findings with the Coxsackie $B$ viruses, glucose levels and glucose tolerance tests were clearly abnormal after infection of mice with the $M$ variant of encephalomyocarditis virus, a known beta-cell pathogen. ${ }^{78}$

Previous studies ${ }^{6} 6$ of Coxsackie virus infections in mice have utilized prototype viral strains with many passages since their original isolation; our results indicate that fresh isolates also do not significantly damage beta-cells or cause glucose intolerance. Though the prototype Coxsackie B2 virus does not damage the pancreas, the present data clearly demonstrate that fresh isolates of Coxsackie B2 may infect and damage acinar cells.

Dr. T. J. Coleman and his colleagues kindly provided a sample of the Coxsackie B4 virus used in their study ${ }^{5}$; we have examined approximately $70 \mathrm{CD}-1$ mice infeoted with this virus. The pathological changes of acinar pancreatitis were sup ported by the finding of hyperamylasaemia during the acute infection. Non-fasting glucose level $(1,2,3,4,5$, and 10 weeks after infection) and glucose tolerance tests ( 1,2 , and 3 weeks after infection) all failed to reveal evidence of glucose intolerance. Histological sections showed no evidence of beta-cell damage. Though we cannot explain the discrepancies between our studies and those of Coleman et al., 5 other work has shown that male CD-1 mice spontaneously develop a diabetic syndrome in response to a high-fat diet.9 Conceivably, Coxsackie B virus infection of CD-1 mice on a high-fat diet might acoelerate the known diabetic tendency of these mice.

Though there may be unusual Coxsackie virus variants, our experiments failed to find any evidence that Coxsackie $B$ viruses can cause a diabetes-like syndrome in mice. -We are, etc.,

Michael E. Ross ABNER LOUIS NOTKINS

Laboratory of Oral Medicine,

National Institute of Dental Research,

Bethesda, Maryland

1 Lancet, 1971, 2, 804.

Pappenheimer, A. M., Kunz, L. J., and
Richardson, S., foumal of Experimental Medicine, 1951, 94, 45 .

Burch, G. E., Tsui, C. Y., Harb, J. M., and Colcolough, G. L., Archives of Internal Medicine, 1971, 128, 40 .

T sui, C. Y., Burch, G. E., and Harb, J. M. Archives of Pathology, 1972, 93, 379.

Coleman, T. J., Gamble, D. R., and Taylor, K. W., British Medical fournal, 1973, 3, 25 .
Ross, M. E., Hayashi, K., and Notkins, A. L., Ross, M. E., Hayashi, K.; and Notkins,

7 Craighead, J., American foumal of Pathology, 1966. 48, 375.

Boucher, D. W $\vec{E}_{\text {Experimental }}$ and Notkins, A. L., foumal of Gleason, R. E., Lauris,
Diabetologia, 1967, 3, 175.

\section{Guitar Nipple}

SIR, - I have recently seen three patients with traumatic mastitis of one breast. These were all girls aged between 8 and 10 and the mastitis consisted of a slightly inflamed cystic swelling about the base of the nipple. Questioning revealed that all three were learning to play the classical guitar, which requires close attention to the position of the instrument in relation to the body. In each case a full-sized guitar was used and the edge of the soundbox pressed against the nipple. Two of the patients were righthanded and consequently had a right-sided mastitis while the third was left-handed with a left-sided mastitis. When the guitarplaying was stopped the mastitis subsided spontaneously.

I would be interested to know whether any other doctors have come across this condition.-I am, etc.,

Winchester.

P. Curtis

\section{Compensation for Dust Disease}

SIR,-After consideration of various relevant matters, the report ${ }^{1}$ referred to in your leading article (9 March, p. 404) concludes that bronchitis and emphysema cannot, on the evidence available, be prescribed at present as industrial diseases in their own right. Many workers with disabling bronchitis have been exposed for many years to mineral dust arising from their respective occupations. These bronchitics, unless they show radiological evidence of pneumoconiosis, are denied industrial disablement benefit under the present regulations.

One proposal, mooted over the years, is that bronchitis should be accepted as liable to aggravation but not caused by long exposure to ocoupational mineral dust. (Incidentally, for the purpose of war pensions in certain cases it is accepted that war service is capable of aggravating bronchitis.) Has aggravation of bronchitis by exposure to occupational mineral dust duly received knowledgeable consideration? If not, does it merit any future consideration?

"Whatsoever things are just ... think on these things."-I am, etc.,

G. B. MURRAY

Sale, Cheshire

Pneumoconiosis and Byssinosis, London.
H.M.S.O., 1973.

\section{New Endotracheal Intubation Trainer}

SIR,-The intubation trainer described here is a readily portable simulator moulded on a human head, with anatomical positions of the structures of the upper respiratory tract located correctly by radiological techniques. Thus, combined with life-like mobility, texture, and colouring of components, the essential anatomy requiring recognition by the trainee is rendered representative of the human adult subject. Its lips are sufficiently supple for manipulation and the mobile lower jaw can be moved forward by up to $2 \mathrm{~cm}$, but only if larynosoope traction is exerted in the correct direction. If backward leverage is employed the top of the laryngoscope automatically dislodges forward from its correct position, thus reminding the trainee to retract the laryngoscope in line with the handle at all times.

A natural tongue-epiglottis-vocal cords configuration provides effective simulation of the laryngoscope blade action. Depressing the tongue reveals the tip of the epiglottis; flexing the epiglottis towards the tongue reveals the vocal cords and entrance to the trachea. The energy required and entrance to the trachea. The energy required to lift the mandible correctly (and safely) is s

to that needed in the average human subject. Inadvertent intubation of the oesophagus can be
demonstrated via the retro-laryngeal pathway. Intubation of the right bronchus is possible owing 